\title{
Characterization of Sentani gudgeon, Oxyeleotris heterodon (Weber, 1907) at Sentani Lake, Papua, Indonesia based on truss morphometric
}

\author{
ABINAWANTO", EKA DEWI SRIYANI, A. BOWOLAKSONO \\ Genetics Laboratory, Department of Biology, Faculty of Mathematics and Natural Sciences, Universitas Indonesia. Jl. Lingkar UI, E Building UI \\ Campus, Depok 16242, West Java, Indonesia. Tel.: +62-21-7270163, Fax.: +62-21-78829010, `email: abinawanto@gmail.com, \\ abinawanto.ms@sci.ui.ac.id
}

Manuscript received: 18 September 2017. Revision accepted: 11 May 2018.

\begin{abstract}
Abinawanto, Sriyani ED, Bowolaksono A. 2018. Characterization of Sentani gudgeon, Oxyeleotris heterodon (Weber, 1907) at Sentani Lake, Papua, Indonesia based on truss morphometric. Biodiversitas 19: 1013-1020. The study concerning the morphometry of Sentani gudgeon (Oxyeleotris heterodon, Weber 1907) was done from August 2016 until April 2017 in Sentani Lake, Jayapura District, Papua Province, Indonesia. The objectives of the study were to find out the diversity of the fish using truss morphometry approach. A total 56 individual sampled from three sampling sites were characterized for their 26 truss morphometric characters. The result showed that there were differences on morphometric characters of Sentani gudgeon. The highest correlation value found in character B2 and D5, which represented the dorsal portion and the tail fin of the fish body respectively. All variables showed significant different between each location (the p-value $<\mathrm{c} 0.05$ ). The canonical diagram resulted of 26 truss morphometric characters illustrated three separated clusters which discriminated the three populations based on sampling sites. A genetic distance analysis among Sentani gudgeon indicated that the fish originated from Putali Village was morphologically closed to the fish population from Sosiri. The truss morphometry technique can be used to identify the diversity of Sentani gudgeon in Sentani Lake.
\end{abstract}

Keywords: Morphometry, Oxyeleotris heterodon, Sentani gudgeon, Sentani Lake, truss morphometry

\section{INTRODUCTION}

Sentani gudgeon (Oxyeleotris heterodon, Weber 1907) is a native fish species living in Sentani Lake, Papua. The fish was categorized as carnivore as it preys Ophieleotris aporos and Crustacean from the genus Macrobrachium as its primary food (Ohee 2013). Sentani gudgeon is promising a high economic value and considers as an important commodity for local fisheries (Coates 1992; Indrayani 2015). Local people around the Sentani Lake are catching and consuming the fish as a protein source, and fortunately, it also provides them with a valuable daily income. However, in the recent years, because of over collection or exploitation and the presence of introduced species, the population of Sentani gudgeon has declined. The introduced species, specifically Striped snakehead (Channa striata) is a potential competitor that seriously threaten the existence of Sentani gudgeon in their native habitat (Rarung and Pratasik 2010). Furthermore, an environmental degradation such as water pollution is also worsening the condition Sentani Lake (Walukow 2012).

As explained by Turan (1999), morphological characters have been used in fish biological studies to estimate the relationship and genetic distance among species that it would be useful in the categorization of the variation in taxonomy. Morphometric characterization is a part of morphological studies focused on quantitative measurement of the size and shape of organisms. In fish biology, morphometric analysis has been used to measure specific characters and relationship among variations in the taxonomy of the fish population stock (Mirsa and Easton 1999). Morphometric variation in the population in different geographic areas may be caused by the difference in genetic and environment condition (Tzeng et al. 2000). Therefore, the distribution and morphometric variation arose are a reasonable response to the physical environments of the population lived.

There are two approaches used to draw morphometric characters, the conventional and truss morphometric methods. truss morphometric method is focusing on the measurement of length and width of specific parts of the fish body, overall known as truss distance, then each measurement was compared to standard or total length. According to Brezki dan Doyle (1988) in Suryaningsih (2012), in the conventional method, the length and width of the body to be measured only in limited items, thus its still too general to describe the fish body.

The truss morphometric method was conducted by measuring length, width, and diagonal of the particular parts of the fish body, and then compared to the standard or total length resulting in a ratio of truss distance (Strauss and Bookstein 1982). In the truss morphometric method, most of the fish body measured. Therefore it would be acquired a more detail of the specific illustration of the body compared to conventional one (Suryaningsih 2012).

The fish morphometric study is beneficial to conduct in order to study the relationship and morphology variation among fish species. Fishes with close similarities and relationship each other would share a lot of similar properties, in contrary, fishes with distance similarities and 
relationship would have a difference in characters. Consequently, all the information would be useful on management and conservation strategies of the species (Khayra 2016).

The research focusing on the fish morphometric study has frequently done, as reported in Lates calcarifer (Gopikhrisna et al. 2006), Chalcalburnus chalcoides (Bagherian and Rahmani 2009), and the Chiclid fish (Fernando and Amarasinghe 2011). However, until recently, the information regarding the morphometric study of Sentani gudgeon in Sentani Lake, Jayapura District, Papua Province, Indonesia still limited. Therefore, the research aimed to identify the diversity Sentani gudgeon living in Sentani Lake, specifically in Ifar Village, Putali Village, and Sosiri Village.

\section{MATERIALS AND METHODS}

The research was done for ten months, from August 2016 to April 2017 in Sentani Lake, Jayapura District, Papua Province, Indonesia (Figure 1). The fish sampling was conducted by purposive sampling based on previously reported by Satria dan Sunarno (2009) which proposed four location of fish conservation areas. We choose only two of the four proposed location, i.e., Putali Village and Ifar Village. As an additional data, we added one location, Sosiri Village situated in distance location and had a different characteristic from the two preferred ones.

In addition, we got a benefit from choosing the locations because in each of three sampling location there were Kampong Nelayan (Fishing village). All samples were collected by many fishermen using a small motorboat. The precise sampling point was recorded its position using Global Positioning System (GPS). Table 1 shows the characteristics of the sampling sites.

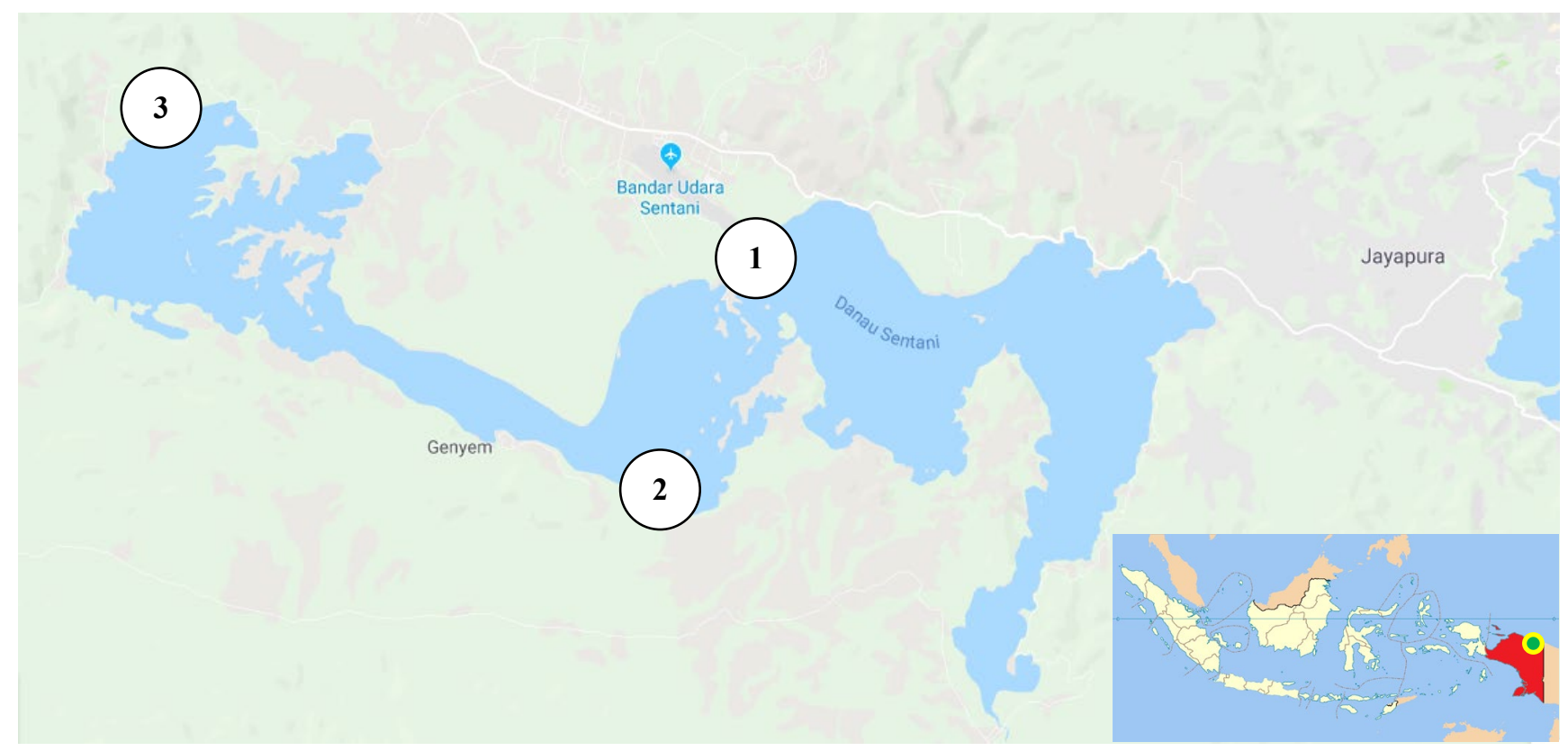

Figure 1. Sampling site location in in Sentani Lake, Jayapura District, Papua Province, Indonesia. 1. Ifar Village, 2. Putali Village, 3. Sosiri Village

Table 1. The characteristics of the sampling location

\begin{tabular}{|c|c|c|}
\hline Sampling location & GPS Position & Characterize \\
\hline Ifar Village & $\begin{array}{l}\text { S } 02^{\circ} 36^{\prime} 13.8^{\prime \prime} \\
\text { E } 140^{\circ} 31^{\prime} 46.3^{\prime \prime}\end{array}$ & $\begin{array}{l}\text { There were abundant submerged plants, such as hydrilla and lotus. In the seashore, } \\
\text { there were higher plants including sago trees. The situs of water inlet found here. } \\
\text { The water depth, 2-6 meter, greenish and turbid (Satria and Sunarno 2009). }\end{array}$ \\
\hline Putali Village & $\begin{array}{l}\mathrm{S} 02^{\circ} 36^{\prime} 59.1^{\prime \prime} \\
\mathrm{E} 140^{\circ} 31^{\prime} 32.1^{\prime \prime}\end{array}$ & $\begin{array}{l}\text { Situated in a bay, it was far from the residential area. In the littoral, there were } \\
\text { many aquatic plants. On the seashore were found sago trees. Water depth } 4-12 \\
\text { meters. The color of the water was green (Satria and Sunarno 2009). }\end{array}$ \\
\hline Sosiri Village & $\begin{array}{l}\mathrm{S} 02^{\circ} 33^{\prime} 41.9^{\prime \prime} \\
\mathrm{E} 140^{\circ} 24^{\prime} 59.2^{\prime \prime}\end{array}$ & Upper lake area, deep water depth and steep (Umar and Makmur 2006). \\
\hline
\end{tabular}


The western part of Sentani Lake was refused as sampling target because the location is a densely populated area dominated by a barren hill. Sentani gudgeon fishes were obtained from a gillnet caught by local fishermen in Sentani Lake fishing villages. The fish were collected in the morning at $07.00-11.00$ (time of middle parts of Indonesia). The samples taken represent from varied sizes were sorted, labeled and stored in styrofoam box and soaked in technical formaldehyde (formalin 40\%). Following 24 hours after fixative soaking, the samples were washed and store in the freezer, and they had already subjected to measurement.

A total of 56 fishes of the Sentani gudgeon which had successfully caught from the three sampling sites were delivered to the laboratory for quantification of their morphological characters. The characters to be measured based on truss distance as previously reported by Atang ey al. (2005). The morphological measurement used $0.01 \mathrm{~mm}$ precision of the digital caliper, and the weight was measured using Ohaus digital scales with $0.1 \mathrm{~g}$ accuracy.

The analysis of the morphometric diversity among 26 characters used correlation analysis and discriminant analysis. Correlation analysis aimed to determine the degree of relationship between the 26 morphometric characters, while the discriminant analysis sought the significant differences among groups based on morphological characters observed. The measurement results were related to the total length, and the results of the measurements will be obtained by grouping according to the morphological characters that can be the differentiating factors. The character is also used to determine the formation or clustering of populations whose analysis was performed using SPSS version 19 based on the principal component analysis (PCA). The results of the main component analysis will be presented in the form of a canonical diagram, and it will use to form a map of population clustering.

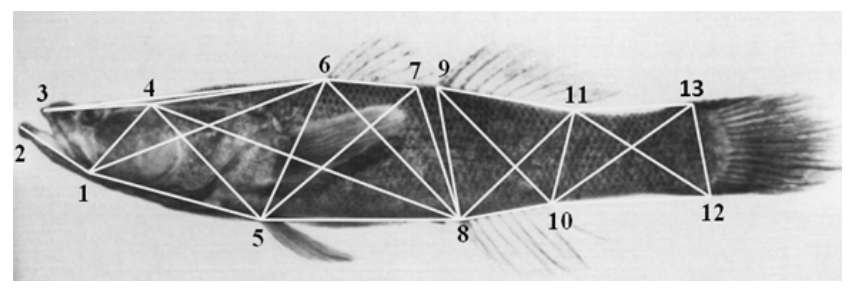

Figure 2. The selected point positions for measurement of morphological characters based on truss morphometric (modified from Allen 1991)

Table 2. Distanced-characters labeling of truss morphometric of the Sentani gudgeon

\begin{tabular}{|c|c|c|}
\hline Parts of the body & Symbol & Explanation \\
\hline \multirow[t]{5}{*}{ Head } & A1 & The base of the lower jaw-the base of the upper snout \\
\hline & A2 & The base of the upper snout - the dorsal end of the head \\
\hline & A3 & The base of the lower jaw - the dorsal end of the head \\
\hline & A4 & The base of the lower jaw - the base of the abdominal fin \\
\hline & A5 & The base of upper snout - the base of the abdominal fin \\
\hline \multirow[t]{10}{*}{ Anterior Body Side } & B1 & The dorsal end of the head - the base of the abdominal fin \\
\hline & $\mathrm{B} 2$ & The dorsal end of the head - the front end of the dorsal fin I \\
\hline & B3 & The base of the lower jaw - the front end of the dorsal fin I \\
\hline & B4 & The dorsal end of the head - the beginning of the anal fin \\
\hline & B5 & The base of the abdominal fin - the front end of the dorsal fin I \\
\hline & B6 & The base of the abdominal fin - the beginning of the anal fin \\
\hline & B7 & The base of the abdominal fin - the back end of the dorsal fin I \\
\hline & B8 & The front end of the dorsal fin I - the back end of the dorsal fin I \\
\hline & B9 & The front end of the dorsal fin I - the beginning of the anal fin \\
\hline & $\mathrm{B} 10$ & The back end of the dorsal fin I - the beginning of the anal fin \\
\hline \multirow[t]{6}{*}{ Posterior Body Side } & $\mathrm{C} 1$ & The beginning of anal fin - front end of dorsal fin II \\
\hline & $\mathrm{C} 2$ & The beginning of anal fin - rear end of anal fin \\
\hline & $\mathrm{C} 3$ & Beginning of anal fin - back end of dorsal fin II \\
\hline & $\mathrm{C} 4$ & The front end of the dorsal fin II - the back end of the anal fin \\
\hline & C5 & The front end of the dorsal fin II - the back end of the second dorsal fin \\
\hline & C6 & The back end of the anal fin - the back end of the second dorsal fin \\
\hline \multirow[t]{5}{*}{ Tail } & D1 & The back end of the anal fin - the base of the lower tail joint \\
\hline & $\mathrm{D} 2$ & The back end of the anal fin - the base of the upper tail joint \\
\hline & D3 & The back end of the dorsal fin II - the base of the lower tail joint \\
\hline & D4 & The back end of the dorsal fin II - the base of the upper tail joint \\
\hline & D5 & The base of the lower tail joint - the base of the upper tail joint \\
\hline
\end{tabular}




\section{RESULTS AND DISCUSSION}

\section{Results}

A total of 56 fishes of Sentani gudgeon sampled, consisting of 35 males and 21 females. The fish samples have a range in the body length between $176.48 \mathrm{~mm}$ and $413.05 \mathrm{~mm}$. Both the longest and the shortest one were found in samples from Ifar Village. Furthermore, their total weight has a range between $49.72 \mathrm{~g}$ and $1270.80 \mathrm{~g}$. The lightest sample was found in Ifar Village, while the heaviest one was found in Sosiri Village. The detailed of sex ratio (male/female) found in the three sampling sites were as followed; Ifar Village (6/8), Putali Village (12/5), and Sosiri Village 917/8).

Correlation analysis shown in table 3 indicate that there was a high correlation between variables. The lowest correlation value, 0,278, was found between variable A1 and A4. Conversely, the highest correlation, 0,963 was situated between D5 and B2 characters. Furthermore, the discriminant analysis of variables indicated that almost all variable except $\mathrm{A} 4$ have value $<0.05$.

The population structure can be seen through the pattern of population grouping of morphological characters that have been analyzed. The data has been obtained is the result of measurement of morphometric truss. In addition, data obtained from measurements of morphometric truss can also be used to see the relationship of Sentani gudgeon population from three sampling sites.

Table 4. Discriminant analysis of morphometric characters of Sentani gudgeon (Oxyeleotris heterodon)

\begin{tabular}{lllccc}
\hline Characteristic & Wilks Lambda & F & df1 & df2 & Sig. \\
\hline A1 & 0.742 & 9.211 & 2 & 53 & .000 \\
A2 & 0.715 & 10.587 & 2 & 53 & .000 \\
A3 & 0.422 & 36.293 & 2 & 53 & .000 \\
A4 & 0.913 & 2.520 & 2 & 53 & .000 \\
A5 & 0.616 & 16.499 & 2 & 53 & .000 \\
B1 & 0.365 & 46.139 & 2 & 53 & .000 \\
B2 & 0.611 & 16.886 & 2 & 53 & .000 \\
B3 & 0.652 & 14.121 & 2 & 53 & .000 \\
B4 & 0.666 & 13.274 & 2 & 53 & .000 \\
B5 & 0.661 & 13.612 & 2 & 53 & .000 \\
B6 & 0.71 & 10.829 & 2 & 53 & .000 \\
B7 & 0.697 & 11.506 & 2 & 53 & .000 \\
B8 & 0.683 & 12.303 & 2 & 53 & .000 \\
B9 & 0.597 & 17.882 & 2 & 53 & .000 \\
B10 & 0.55 & 21.657 & 2 & 53 & .000 \\
C1 & 0.578 & 19.377 & 2 & 53 & .000 \\
C2 & 0.756 & 8.534 & 2 & 53 & .001 \\
C3 & 0.507 & 25.819 & 2 & 53 & .000 \\
C4 & 0.576 & 19.535 & 2 & 53 & .000 \\
C5 & 0.598 & 17.833 & 2 & 53 & .000 \\
C6 & 0.645 & 14.599 & 2 & 53 & .000 \\
D1 & 0.44 & 33.767 & 2 & 53 & .000 \\
D2 & 0.442 & 33.411 & 2 & 53 & .000 \\
D3 & 0.528 & 23.665 & 2 & 53 & .000 \\
D4 & 0.434 & 34.595 & 2 & 53 & .000 \\
D5 & 0.652 & 14.147 & 2 & 53 & .000 \\
\hline & & & & & \\
\hline
\end{tabular}

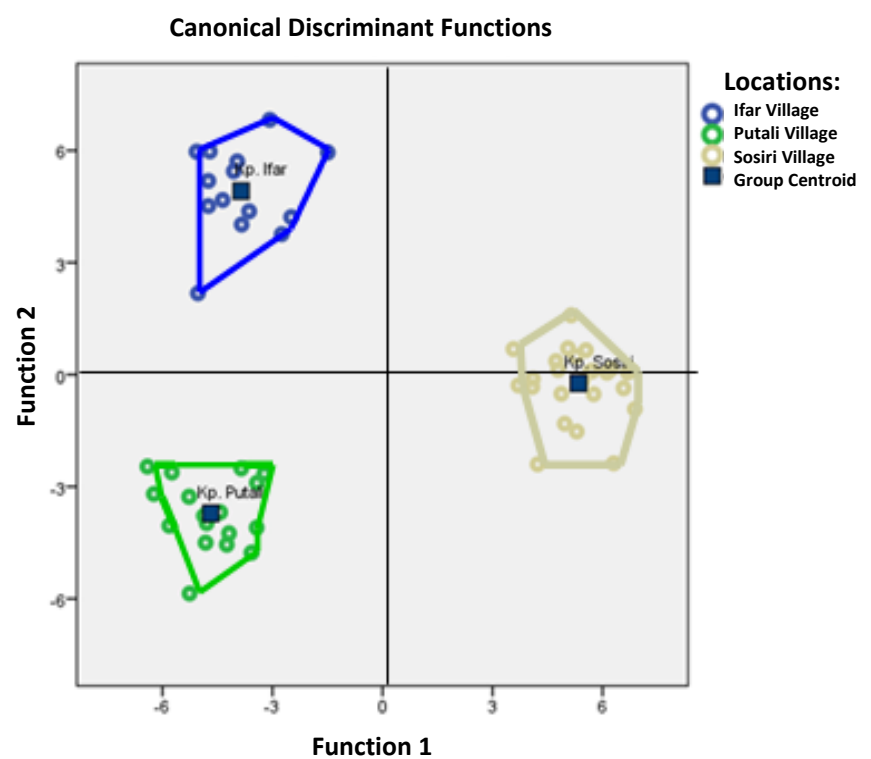

Figure 3. The pattern of population clustering based on truss morphometric measurement

Tabel 5. The coefficient of variation of each morphometric characters

\begin{tabular}{ll}
\hline Characteristic & Coefficient of variation \\
\hline A1 & 25.38 \\
A2 & 20.81 \\
A3 & 30.64 \\
A4 & 216.55 \\
A5 & 28.78 \\
& \\
B1 & 36.96 \\
B2 & 23.58 \\
B3 & 16.76 \\
B4 & 31.16 \\
B5 & 37.84 \\
B6 & 18.85 \\
B7 & 36.46 \\
B8 & 38.92 \\
B9 & 31.05 \\
B10 & 28.78 \\
C1 & \\
C2 & 32.16 \\
C3 & 22.25 \\
C4 & 37.95 \\
C5 & 29.17 \\
C6 & 26.51 \\
& 27.08 \\
D1 & \\
D2 & 30.54 \\
D3 & 29.79 \\
D4 & 28.44 \\
D5 & 30.27 \\
Note: The coefficient of variation & 29.49 \\
\hline
\end{tabular}


Table 3. Correlation analysis of 26 truss morphometric characters of Sentani gudgeon (Oxyeleotris heterodon)

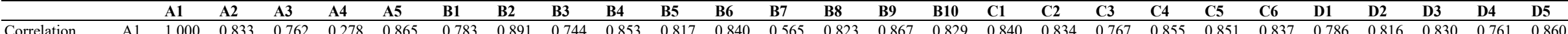

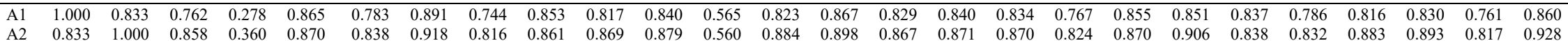

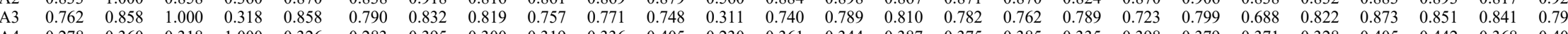

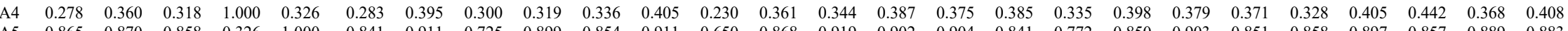

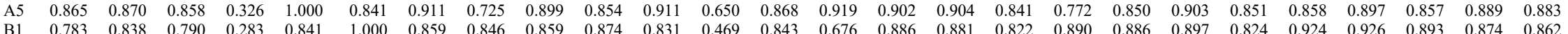
$\begin{array}{llllllllllllllllllllllllllllll}\mathrm{B} 1 & 0.783 & 0.838 & 0.790 & 0.283 & 0.841 & 1.000 & 0.859 & 0.846 & 0.859 & 0.874 & 0.831 & 0.469 & 0.843 & 0.676 & 0.886 & 0.881 & 0.822 & 0.890 & 0.886 & 0.897 & 0.824 & 0.924 & 0.926 & 0.893 & 0.874 & 0.862 \\ \mathrm{~B} 2 & 0.891 & 0.918 & 0.832 & 0.395 & 0.911 & 0.895 & 1.000 & 0.861 & 0.942 & 0.923 & 0.933 & 0.586 & 0.931 & 0.953 & 0.942 & 0.950 & 0.915 & 0.910 & 0.948 & 0.954 & 0.915 & 0.918 & 0.947 & 0.956 & 0.889 & 0.963\end{array}$

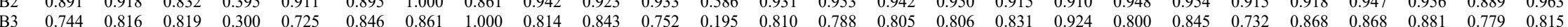

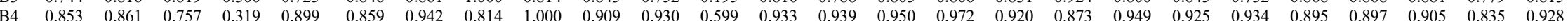
$\begin{array}{lllllllllllllllllllllllllllll}\text { B5 } & 0.817 & 0.869 & 0.771 & 0.336 & 0.854 & 0.874 & 0.923 & 0.843 & 0.909 & 1.000 & 0.873 & 0.585 & 0.902 & 0.916 & 0.911 & 0.914 & 0.872 & 0.860 & 0.905 & 0.928 & 0.881 & 0.852 & 0.876 & 0.857 & 0.844 & 0.924\end{array}$ $\begin{array}{llllllllllllllllllllllllllll}\text { B6 } & 0.840 & 0.879 & 0.748 & 0.405 & 0.911 & 0.831 & 0.933 & 0.752 & 0.930 & 0.873 & 1.000 & 0.709 & 0.905 & 0.916 & 0.921 & 0.931 & 0.899 & 0.787 & 0.932 & 0.906 & 0.913 & 0.853 & 0.896 & 0.879 & 0.829 & 0.923\end{array}$ $\begin{array}{llllllllllllllllllllllllllll}\mathrm{B} 7 & 0.565 & 0.560 & 0.311 & 0.230 & 0.650 & 0.469 & 0.856 & 0.159 & 0.599 & 0.585 & 0.709 & 1.000 & 0.578 & 0.647 & 0.588 & 0.601 & 0.529 & 0.292 & 0.648 & 0.573 & 0.640 & 0.437 & 0.458 & 0.425 & 0.485 & 0.605\end{array}$

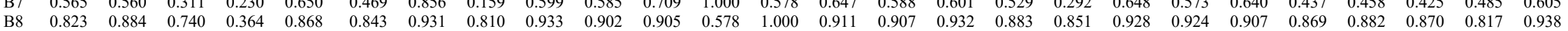

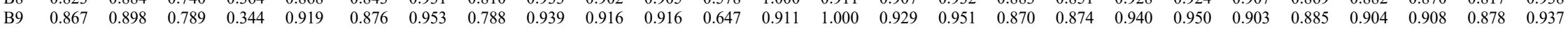

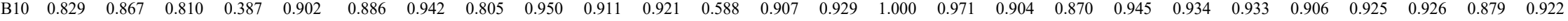
$\begin{array}{llllllllllllllllllllllllllll}\mathrm{C} 1 & 0.840 & 0.871 & 0.782 & 0.375 & 0.904 & 0.881 & 0.950 & 0.806 & 0.972 & 0.914 & 0.931 & 0.601 & 0.932 & 0.951 & 0.971 & 1.000 & 0.919 & 0.887 & 0.958 & 0.937 & 0.943 & 0.902 & 0.924 & 0.925 & 0.872 & 0.941\end{array}$ $\begin{array}{lllllllllllllllllllllllllllllll}\mathrm{C} 2 & 0.834 & 0.870 & 0.762 & 0.385 & 0.841 & 0.822 & 0.915 & 0.831 & 0.920 & 0.872 & 0.899 & 0.529 & 0.883 & 0.870 & 0.904 & 0.919 & 1.000 & 0.872 & 0.920 & 0.902 & 0.917 & 0.870 & 0.890 & 0.907 & 0.807 & 0.904\end{array}$

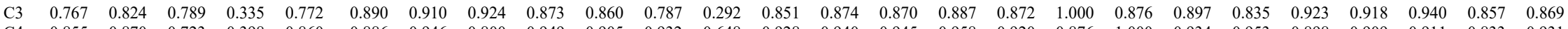

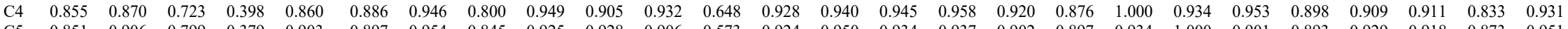

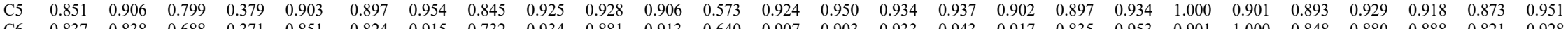
$\begin{array}{lllllllllllllllllllllllllll}\text { C6 } & 0.837 & 0.838 & 0.688 & 0.371 & 0.851 & 0.824 & 0.915 & 0.732 & 0.934 & 0.881 & 0.913 & 0.640 & 0.907 & 0.903 & 0.933 & 0.943 & 0.917 & 0.835 & 0.953 & 0.901 & 1.000 & 0.848 & 0.880 & 0.888 & 0.821 & 0.928 \\ \text { D1 } & 0.786 & 0.832 & 0.822 & 0.328 & 0.858 & 0.924 & 0.918 & 0.868 & 0.896 & 0.852 & 0.853 & 0.437 & 0.869 & 0.885 & 0.906 & 0.902 & 0.870 & 0.923 & 0.898 & 0.893 & 0.848 & 1.000 & 0.944 & 0.936 & 0.917 & 0.864\end{array}$ $\begin{array}{lllllllllllllllllllllllllll}\mathrm{D} 2 & 0.786 & 0.832 & 0.822 & 0.328 & 0.858 & 0.924 & 0.918 & 0.868 & 0.896 & 0.852 & 0.853 & 0.437 & 0.869 & 0.885 & 0.906 & 0.92 & 0.870 & 0.923 & 0.898 & 0.893 & 0.848 & 1.000 & 0.944 & 0.936 & 0.917 & 0.864 \\ \mathrm{D} 2 & 0.816 & 0.883 & 0.873 & 0.405 & 0.897 & 0.926 & 0.947 & 0.868 & 0.997 & 0.876 & 0.896 & 0.458 & 0.882 & 0.904 & 0.925 & 0.924 & 0.890 & 0.918 & 0.909 & 0.929 & 0.880 & 0.944 & 1.000 & 0.961 & 0.921 & 0.917\end{array}$

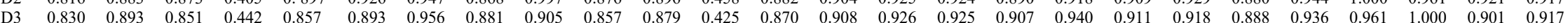
$\begin{array}{llllllllllllllllllllllllllll}\text { D4 } & 0.761 & 0.817 & 0.841 & 0.368 & 0.889 & 0.874 & 0.889 & 0.779 & 0.835 & 0.844 & 0.829 & 0.485 & 0.817 & 0.878 & 0.879 & 0.872 & 0.807 & 0.857 & 0.833 & 0.873 & 0.821 & 0.917 & 0.921 & 0.901 & 1.000 & 0.846\end{array}$ $\begin{array}{llllllllllllllllllllllllllllll}\text { D5 } & 0.860 & 0.928 & 0.795 & 0.408 & 0.883 & 0.862 & 0.963 & 0.815 & 0.928 & 0.924 & 0.923 & 0.605 & 0.938 & 0.937 & 0.922 & 0.941 & 0.904 & 0.869 & 0.931 & 0.951 & 0.928 & 0.864 & 0.917 & 0.917 & 0.846 & 1.000\end{array}$

$\begin{array}{lllllllllllllllllllllllllllll}\text { Sig.(1-tailed) } & \text { A1 } & 0.000 & 0.000 & 0.019 & 0.000 & 0.000 & 0.000 & 0.000 & 0.000 & 0.000 & 0.000 & 0.000 & 0.000 & 0.000 & 0.000 & 0.000 & 0.000 & 0.000 & 0.000 & 0.000 & 0.000 & 0.000 & 0.000 & 0.000 & 0.000 & 0.000\end{array}$ $\begin{array}{lllllllllllllllllllllllllll}\text { A2 } & 0.000 & 0.000 & 0.003 & 0.000 & 0.000 & 0.000 & 0.000 & 0.000 & 0.000 & 0.000 & 0.000 & 0.000 & 0.000 & 0.000 & 0.000 & 0.000 & 0.000 & 0.000 & 0.000 & 0.000 & 0.000 & 0.000 & 0.000 & 0.000 & 0.000\end{array}$

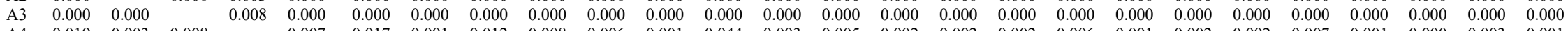

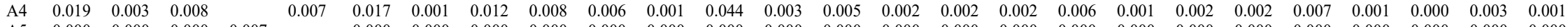
$\begin{array}{llllllllllllllllllllllllllll}\text { A5 } & 0.000 & 0.000 & 0.000 & 0.007 & & 0.000 & 0.000 & 0.000 & 0.000 & 0.000 & 0.000 & 0.000 & 0.000 & 0.000 & 0.000 & 0.000 & 0.000 & 0.000 & 0.000 & 0.000 & 0.000 & 0.000 & 0.000 & 0.000 & 0.000 & 0.000 & 0.000\end{array}$ $\begin{array}{llllllllllllllllllllllllllll}\mathrm{B} 2 & 0.000 & 0.000 & 0.000 & 0.001 & 0.000 & 0.000 & & 0.000 & 0.000 & 0.000 & 0.000 & 0.000 & 0.000 & 0.000 & 0.000 & 0.000 & 0.000 & 0.000 & 0.000 & 0.000 & 0.000 & 0.000 & 0.000 & 0.000 & 0.000 & 0.000\end{array}$

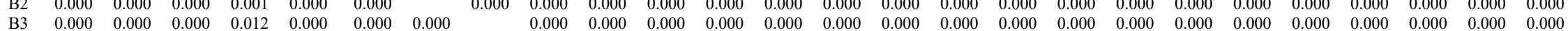

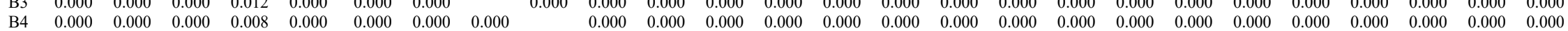
$\begin{array}{llllllllllllllllllllllllllll}\mathrm{B} 5 & 0.000 & 0.000 & 0.000 & 0.006 & 0.000 & 0.000 & 0.000 & 0.000 & 0.000 & & 0.000 & 0.000 & 0.000 & 0.000 & 0.000 & 0.000 & 0.000 & 0.000 & 0.000 & 0.000 & 0.000 & 0.000 & 0.000 & 0.000 & 0.000 & 0.000\end{array}$

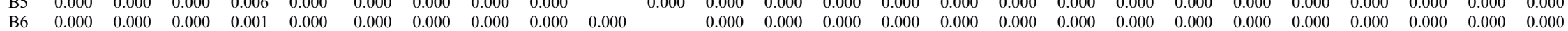
$\begin{array}{lllllllllllllllllllllllllllll}\text { B7 } & 0.000 & 0.000 & 0.010 & 0.044 & 0.000 & 0.000 & 0.000 & 0.075 & 0.000 & 0.000 & 0.000 & 0.000 & 0.000 & 0.000 & 0.000 & 0.000 & 0.015 & 0.000 & 0.000 & 0.000 & 0.000 & 0.000 & 0.001 & 0.000 & 0.000\end{array}$ $\begin{array}{llllllllllllllllllllllllll}\text { B8 } & 0.000 & 0.000 & 0.000 & 0.003 & 0.000 & 0.000 & 0.000 & 0.000 & 0.000 & 0.000 & 0.000 & 0.000 & 0.000 & 0.000 & 0.000 & 0.000 & 0.000 & 0.000 & 0.000 & 0.000 & 0.000 & 0.000 & 0.000 & 0.000 & 0.000\end{array}$

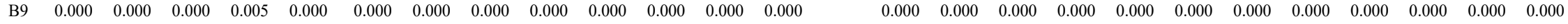
$\begin{array}{llllllllllllllllllllllllll}\mathrm{B} 10 & 0.000 & 0.000 & 0.000 & 0.002 & 0.000 & 0.000 & 0.000 & 0.000 & 0.000 & 0.000 & 0.000 & 0.000 & 0.000 & 0.000 & 0.000 & 0.000 & 0.000 & 0.000 & 0.000 & 0.000 & 0.000 & 0.000 & 0.000 & 0.000 & 0.000\end{array}$

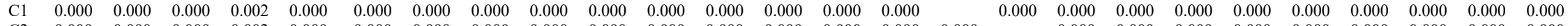

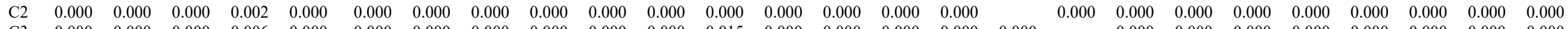

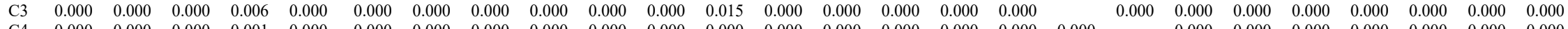

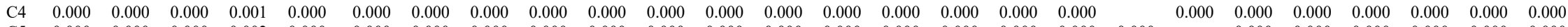

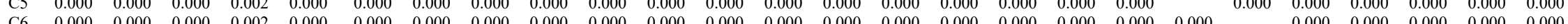
$\begin{array}{lllllllllllllllllllllllllll}\mathrm{D} 1 & 0.000 & 0.000 & 0.000 & 0.007 & 0.000 & 0.000 & 0.000 & 0.000 & 0.000 & 0.000 & 0.000 & 0.000 & 0.000 & 0.000 & 0.00 & 0.000 & 0.000 & 0.000 & 0.000 & 0.000 & 0.000 & 0.000 & 0.000 & 0.000 & 0.000 & 0.000\end{array}$ $\begin{array}{llllllllllllllllllllllllllllllllll}\mathrm{D} 2 & 0.000 & 0.000 & 0.000 & 0.001 & 0.000 & 0.000 & 0.000 & 0.000 & 0.000 & 0.000 & 0.000 & 0.000 & 0.000 & 0.000 & 0.000 & 0.000 & 0.000 & 0.000 & 0.000 & 0.000 & 0.000 & 0.000 & & 0.000 & 0.000 & 0.000\end{array}$ $\begin{array}{llllllllllllllllllllllllll}\text { D3 } & 0.000 & 0.000 & 0.000 & 0.000 & 0.000 & 0.000 & 0.000 & 0.000 & 0.000 & 0.000 & 0.000 & 0.001 & 0.000 & 0.000 & 0.000 & 0.000 & 0.000 & 0.000 & 0.000 & 0.000 & 0.000 & 0.000 & 0.000 & 0.000 & 0.000\end{array}$ \begin{tabular}{llllllllllllllllllllllllll} 
D4 & 0.000 & 0.000 & 0.000 & 0.003 & 0.000 & 0.000 & 0.000 & 0.000 & 0.000 & 0.000 & 0.000 & 0.000 & 0.000 & 0.000 & 0.000 & 0.000 & 0.000 & 0.000 & 0.000 & 0.000 & 0.000 & 0.000 & 0.000 & 0.000 & \\
D5 & 0.000 & 0.000 & 0.000 & 0.001 & 0.000 & 0.000 & 0.000 & 0.000 & 0.000 & 0.000 & 0.000 & 0.000 & 0.000 & 0.000 & 0.000 & 0.000 & 0.000 & 0.000 & 0.000 & 0.000 & 0.000 & 0.000 & 0.000 & 0.000 & 0.000 \\
\hline
\end{tabular} 
Table 6. The matrix of genetic distance values between sampling location which indicated the genetic relationship among Sentani gudgeon (Oxyeleotris heterodon)

\begin{tabular}{llll}
\hline Population & Ifar Village & Putali Village & Sosiri Village \\
\hline Ifar Village & 0 & & \\
Putali Village & 0.120 & 0 & \\
Sosiri Village & 0.068 & 0.065 & 0 \\
\hline
\end{tabular}

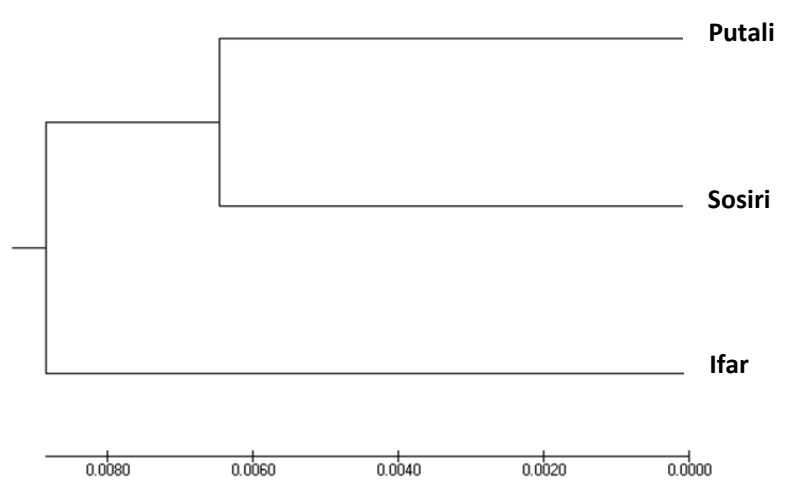

Figure 4. A dendrogram of genetic distance among Sentani gudgeon (Oxyeleotris heterodon) based on truss morphometrics.

Analysis of 26 characters indicates that the morphometric characters of each population in three different locations (Ifar Village, Sosiri Village, and Putali Village) have different characteristics. Homogeneous characteristics are specified by each location, meaning that the characteristics differ significantly ( $p$-value $<0.05$ ).

The distribution pattern between populations, which was separated the three villages into three clusters, based on morphological analysis and canonical diagram was shown in figure 3. The centroid group from Sosiri Village is right on the $\mathrm{X}$ line, while the centroid group from Putali Village and Ifar Village is far away on the $\mathrm{X}$ and $\mathrm{Y}$ axes. Further, as the result of truss morphometric analysis of Oxyeleotris heterodon, were also shown the genetic distance value which indicated the relationship among Sentani gudgeon (Table 6).

The furthest relationship was the population of Sentani gudgeon originating from Putali Village with Ifar Village of 0.120 while the closest relationship was the population from Putali Village with Sosiri Village which is 0.065 .

As shown in the dendrogram, the relationship among Sentani gudgeon (Oxyeleotris heterodon) population is depicted in two main clusters (Figure 4). The population of the Putali Village is one group with Sosiri Village, whereas a separate group is a population from the Ifar village.

\section{Discussion}

Earlier studies suggested the effectiveness of truss morphometric technique in identifying the fish diversity, especially among species which have high similarities. As reported by Muchlisin (2013), the technique was successfully applied in discrimination of three clusters of Rasbora fish in Danau (lake) Laut Tawar. A similar result was also explained by Fernando and Amarasinghe (2011) in two species of Cichlid fish in Sri Lanka estuaries. However, until recently, morphometric research using truss morphometric approach has not been conducted in Sentani gudgeon. The fish has limited distribution area, in Papua they can be found in Sentani Lake.

Correlation analysis of 26 characters of truss morphometric of Sentani gudgeon showed the lowest value, 0.278 , situated between A1 and A4. Meanwhile, the highest correlation, 0.963 , devoted to D5 and B2. While The B2 represented a character of the dorsal portion of the fish pointed to a line from the dorsal end of the head to the front end of dorsal find I, the D5 is a line of the base of the lower tail joint - the base of the upper tail joint. The high correlation value, almost $100 \%$, between B2 and D5 indicate that increasing length of B2 character coincides with the increasing length of D5 character. The dorsal portion of fish represented by B2 character would also significantly influenced the parameter of weight and height of the fish body. When the fish grew in height and increased its dorsal portion weight due to lipid deposit, so the B5 character which represented the tail fin also increase its hight. The synchronization of the growth behavior can be attributed to the movement of fish. The fish's back is getting taller and heavier, so it needs a high, big and strong tail fin. Therefore, when the B2 character increases, the D5 character increases.

Previous studies by Atang et al. (2015) reported the successful use of truss morphometric approach in the sex determination of the seed of Marble goby (Oxyeleotris marmorata). They claimed that the characters of A2, A4, B5, and B6 were significantly different. Due to the continuing growth of the seeds were affected by many factors so that the growing character between adult and seeds were probably different. However, in the recent study, measurements on Sentani gudgeon morphometry were not performed on the seeds. Interestingly, there were similarities between research conducted by Atang et al. (2015) with a morphometric study of Sentani gudgeon particularly in the growth occurred vertically and horizontally. The D5 character in Sentani gudgeon showed vertical growth, whereas in fish betutu is found on characters A2, A4, and B6. Horizontal growth in Sentani gudgeon occurred in character B2, whereas in fish betutu it found in character B5.

Sentani gudgeon has morphological characters that can be used for differentiation purpose. Testing through discriminant analysis resulting in value $<0.01$, meaning that the truss morphometric can be used to identify the diversity of Sentani gudgeon populated in Lake Sentani. The technique can also identify the population structure in the form of the spreading or clustering of the population. The canonical diagram illustrated in Figure 3 showed the morphological character of Sentani gudgeon from three separate populations.

The clustering pattern seen in canonical diagrams were considered due to the behavioral type of the Sentani gudgeon that tends to be passive, similar to the nature of 
the betutu fish, its close relative in the same genus. Betutu fish can stand for hours without shifting from its place, the reason why it is often referred to as lazy fish (Astuti et al. 2000). Furthermore, the lazy characteristic has caused Sentani gudgeon does not have wide dispersal area and their mating system were limited to the individuals residing in that population. This behavior might lead the character of the population in each location is not so varied. The next possibility is that there are no breading efforts between the population of Sentani gudgeon originating from other regions, for example from Papua New Guinea. Such efforts possibly may add to the morphological variation of the Sentani gudgeon found on Lake Sentani. According to research conducted Muharran et al. (2012) in koi carp, breeding activities can add morphological variation in koi carp populations. The last possibility due to past geological events that occurred in Lake Sentani and causing the population of Sentani gudgeon lived in Lake Sentani has morphological variations that cluster according to their habitat. This is most likely to happen in-breeding if it persists. The canonical diagram formed showed that the population of Sentani gudgeon should be subject to breeding.

The genetic distance is the degree of gene differences between species or between populations in species that can indicate genetic relationships. The genetic distance value has a range of $0-1$. A value of 0 indicates that allele frequencies in both populations are equal, and when the value is 1 if both populations do not have the same allele. The higher the genetic distance, the more the genetic relationship between these populations (Nei 1987). The result of the truss morphometric measurement shown the farthest genetic distance situated between the population of Sosiri Village and Ifar Village, while the closest genetic distance is from the population of Sosiri Village with Putali Village. Visible on the map, based on the geographical location of the three sites, the distance between Putali Village is closer to Ifar Village compared to Putali Village, but in fact, the population has a far genetic distance. This can be due to geographical factors such as the depth of Lake Sentani. According to the bathymetry map of Sentani Lake between Putali Village and Ifar Village, the depth is more than 50 meters, so there is little gene exchange or no gene exchange at all. The population of Sosiri Village is closer to Putali Village. This is possible due to the two locations are separated by Simporo Strait which is not very deep, so it eases the movement of Sentani gudgeon (Oxyeleotris heterodon). The depth of the Simporo Strait is less than 50 meters (Indrayani et al. 2015).

The dendrogram construction showed the three populations divided into two clusters. The population that came from Sosiri Village join the cluster with population from Putali Village. The population from Ifar Village was isolated as a single cluster so that the gene differences and genetic distance between the two groups were very large. The study of the migratory pattern of the typical Striped snakehead (Channa striata), which is a species of the same family as the Sentani gudgeon, indicates that the fish have low migratory and seasonal unaffected capabilities (Halls et al., 1998). Populations that have low migration tend to retain their morphological characters on a descending scale. Similar results obtained by Budiharjo (2001) on Silver barb or tawes (Barbodes gonionotus) who examine the fish in three different habitats. In the lake habitats contained within the cave caused changes and morphological differences in tawes populations due to environmental factors. One environmental factor that is temperature is one factor that can cause morphological changes. If during the development of a fish embryo at a temperature lower than its optimum temperature and continues from one generation to the next it can stimulate the number of vertebrates to maximize in its variation. This factor is thought to have the most influence on the change in the number of tawes in the lake vertebrates contained in the Cave Seropan, Sewu Mountains, Indonesia.

Results from the calculation of the genetic distance and visualization of the dendrogram provide an overview of the strategies of conservation conducted on Sentani gudgeon. The breeding programs should be done, especially for populations from Sosiri Village or Putali Village with populations from Ifar Village. If there is no crossing, it is likely that in the future there will be in-breeding of Sentani gudgeon population at every location, especially in the population in Ifar Village with Putali Village which will be used as fishery sanctuary.

Research by Indriyani (2015) on the availability of plankton and benthos as a food source, it is seen that the waters of Sentani Lake are still supporting organisms living in this area. Some of the physical and chemical parameters of the waters of some conditions have exceeded the water quality standard threshold. The content of $\mathrm{pH}$ in Lake Sentani is neutral tend to alkali, this is due to the limestone hills found in Cyclop Mountain that surround Lake Sentani. Lime enters Lake Sentani through the process of erosion through the rain. Ammonia content (NH3) should not exist in water, but in Lake Sentani already contain the material that is as much as $0.003-0.53 \mathrm{mg} / \mathrm{L}$, it means that there is contamination that if not prevented will endanger the organism in Lake Sentani including Sentani gudgeon.

In conclusion, the diversity of Sentani gudgeon (Oxyeleotris heterodon) morphology measured from 26 morphometric characters, there are two distinct characters, and 24 characters are not significantly different. The dispersion of phenotype based on discriminant analysis yielding canonical diagram shows three groupings of Sentani gudgeon based on the morphometric analysis. truss morphometric can reveal the diversity of Sentani gudgeon in Sentani Lake.

\section{ACKNOWLEDGMENTS}

The authors would like to thank Dr. Henny Ohee (Universitas Cenderawasih, Jayapura, Indonesia) and Dr. Kadarusman (Polytechnic of Marine and Fisheries, Sorong, Indonesia) for valuable suggestion. This work was supported by The Directorate for Research and Community Services, Universitas Indonesia. A project funded by the Hibah Pitta 2016 (No.1990/UN2.R12/HKP.05.00/2016). 


\section{REFERENCES}

Allen GR. 1991. Field Guide to the Freshwater Fishes of New Guinea, Publication No. 9. Christensen Research Institute, Madang, Papua New Guinea.

Astuty S, Diana S, Iskandar. 2000. Biology study of betutu fish (Oxyeleotris marmorata) in Cirata dam. Jurnal Bionatura 2 (1): 21-22. [Indonesian]

Atang S, Suryaningsih, Abulias MN. 2015. Sex determination of betutu broodstock (Oxyeleotris marmorata Blkr.) by truss morphometrics analysis. Biosfera 32 (1): 29-34 [Indonesian].

Bagherian A, Rahmani H. 2009. Morphological discrimination between two populations of shemaya, Chalcalburnus chalcoides (Actinopterygii, Cyprinidae) using a truss network. Anim Biodiv Conserv 32 (1): 1-8.

Budiharjo A. 2001. Morphological characters of Java Barb, Barbodes gonionotus in Gua Serpeng Lake, Gunung Kidul. Biodiversitas 2 (1): 104-109 [Indonesian].

Coates D. 1992. Biology of Oxyeleotris heterodon and its major prey, Ophieleotris aporos, two floodplain sleepers (Pisces: Eleotridae) of the Sepik River Fishery, Northen Papua New Guinea. Environ Biol Fish 34 (1): 51-64.

Fernando GKAW, Amarasinghe US. 2011. Morphological differentiation of two cichlid species in Sri Lanka using truss networks. Sri Lanka J Aquat Sci 16: 1-10.

Halls AS, Hoggarth DD, Debnath K. 1998. Impact of flood control schemes on river fish migrations and species assemblages in Bangladesh. J Fish Biol 53: 358-380.

Indrayani E, Nitimulyo KH, Hadisusanto S, Rustandi. 2015. Bathymetry map of Sentani Lake, Papua. Depik 4 (3): 116-120. [Indonesian]

Indrayani E. 2015. Carrying capacity in Sentani Lake for fisheries based on Carbon (C), Nitrogen (N), and Phosphor (P), respectively. [Dissertation]. Faculty of Biology, Gajah Mada University, Yogyakarta. [Indonesian]

Khayra A, Muchlisin ZA, Sarong MA. 2016. Morphometric of five fish species which is dominant in Aneuk Laot Lake, Sabang. Depik 5 (2): 57-66 [Indonesian]
Misra RK, Easton MDL. 1999. A note on the number of morphometric characters used in fish stock delineation studies employing a Manova. J Fish Res 42: 191-194.

Muchlisin ZA. 2013. Morphometric variations of Rasbora group (Pisces: Cyprinidae) in Lake Laut Tawar, Aceh Province Indonesia based on truss character analysis. Hayati 20 (3): 138-143.

Muharam EG, Buwono ID, Mulyani Y. 2012. Relationship analysis among Cyprinus carpio koi and Cyprinus carpio carpio by RAPD method. Jurnal Perikanan dan Kelautan 3 (3): 15-23. [Indonesian]

Nei M. 1987. Molecular Evolutionary Genetics. Columbia University Press, New York.

Ohee HL. 2013. The ecology of the red rainbowfish (Glossolepis incisus) and the impact of human activities on its habitats in Sentani Lake, Papua. [Dissertation]. Division of Mathematics and Natural Sciences, Georg-August Universität Göttingen, Germany.

Rarung LK, Pratasik SB. 2010. Freshwater fish management in watershed of Digoel river, Papua. Jurnal Perikanan dan Kelautan 6 (1): 41-45 [Indonesian].

Satria H, Sunarno MTD. 2009. Habitat characteristics of Sentani Lake as a prospective asylum fishery. Bawal 2 (4): 163-169 [Indonesian]

Strauss RE, Bookstein FL. 1982. The truss: body form reconstructions in morphometrics. Syst Zool 31 (2): 113-135.

Suryaningsih S. 2012. Morphometric and reproduction character of Puntius orphoides (Valenciennes, 1842) and P. javanicus (Bleeker, 1863) in Klawing river, Purbalingga, Central Java. [Dissertation]. Faculty of Biology, Gajah Mada University, Yogyakarta. [Indonesian]

Turan C. 1999. A Note on the examination of morphometric differentiation among fish population: The truss system. Journal of Zoology 23: 259-263.

Tzeng TD, Chiu CS, Yeh SY. 2000. Morphometric variation in red-spot prawn (Metapenaeopsis barbata) in different geographic waters of Taiwan. J Fish Res 53: 211-217.

Umar C, Makmur S. 2006. Fish species composition by catch in Sentani Lake, Papua. Biodiversitas 7 (4): 349-353. [Indonesian]

Walukow AF. 2012. The policy analysis of reducing forest cover in the Sentani River basin environmental insight. Jurnal Manusia dan Lingkungan 19 (1): 74-84. [Indonesian] 